Mariusz CHROSTOWSKI

DOI : $10.14746 / p p .2021 .26 .2 .6$

Katholischen Universität Eichstätt - Ingolstadt

ORCID ID: 0000-0002-5817-2687

\title{
„Bezbożny sojusz”? populizm i wiodące religie monoteistyczne
}

\begin{abstract}
Streszczenie: Populizm to jedno $\mathrm{z}$ największych wyzwań współczesności nie tylko w rozumieniu kulturowym, społecznym i politycznym, ale także religijnym. Niezależnie od tego, czy to judaizm, chrześcijaństwo lub islam, każda z tych religii wraz z jej symbolami, obrazami, metaforami i przypowieściami, jest narażana na mimowolny i „bezbożny sojusz” z populizmem, który wykorzystuje religię do osiągnięcia własnych celów na drodze politycznej manipulacji, potęgowania postaw antyimigranckich, dewaluacji innych grup społecznych, a także antyestablishmentu i antypluralizmu. Celem niniejszego artykułu jest zatem ukazanie relacji, jakie zachodzą pomiędzy populistyczną ,ideologią o cienkim rdzeniu", a głównymi religiami monoteistycznymi w ramach ideologicznego zawłaszczania religii przez populistów, które posiada każdorazowo jednakowy „punkt styczny”, tj. upolitycznienie religii i sakralizację polityki.
\end{abstract}

Slowa kluczowe: populizm, religia, judaizm, chrześcijaństwo, islam

\section{Wstęp}

Dopulistyczna prawica zawiera bezbożny sojuszu z religią” (ang. „The populist right is forging an unholy alliance with religion") - to intrygujący tytuł jednego z wielu artykułów dotyczących populizmu, który ukazał się na przestrzeni ostatnich lat w brytyjskim dzienniku „The Guardian” (Steinmetz-Jenkins, Jäger, 2019). Rzekomy „bezbożny sojusz" jest tym bardziej interesujący, że nie jest zjawiskiem „zarezerwowanym” dla jakiejś jednej, wybranej i szczególnie podatnej na działania populistów religii, lecz dotyczy wszystkich wiodących religii monoteistycznych tj.: judaizmu, chrześcijaństwa $\mathrm{i}$ islamu (Wiedemann, 2016).

Tutaj, niejako samoistnie, rodzi się pytanie: jak to jest możliwe, że religia np.: chrześcijaństwo, odgrywające przecież tak ważną rolę w zapobieganiu ludzkim lękom (Palaver, 2019, 2018), jest źródłem wzmacniania postaw prospołecznych, resiliencji czy kapitału społecznego (zob. m.in. Haggard i in., 2015; Avgoulas, Fanany, 2012; Putnam, Campbell, 2012; Pargament, Cummings, 2010; Pargament i in., 2011; Prado i in., 2004; Surzykiewicz, 2015; Saroglou i in., 2005, 2009), może zostać uwikłane w sidła populistów do tego stopnia, że mówi się o „bezbożnym sojuszu” populizmu $\mathrm{z}$ religią?

Celem niniejszego artykułu, w tak przedstawionym ujęciu, jest ukazanie relacji, jakie zachodzą pomiędzy populistyczną „,ideologią o cienkim rdzeniu" (Mudde, 2004; Mudde, Kaltwasser 2011, 2017) a judaizmem, chrześcijaństwem i islamem w ramach

${ }^{1}$ Rozumienie populizmu jako „ideologii o cienkim rdzeniu” to jedno z wielu istniejących ujęć definicyjnych tego zjawiska, zob. min.: Lipiński, 2020a, b; Marczewska-Rytko, 2011; Gidron, Bonikowski, 2013. 
ideologicznego zawłaszczania religii przez populistów, które ostatecznie prowadzi do jednakowego ,punktu stycznego”: upolitycznienia religii i sakralizacji polityki.

\section{Populizm jako ,ideologia o cienkim rdzeniu”}

Znaczenie pojęcia „ideologia” jest zakorzenione w greckich słowach: idea (i $\delta \delta \varepsilon \alpha)$ - kształt, wyobrażenie, postać, myśl + logos ( W ogólnym zarysie ideologia jest terminem wieloznacznym, używanym w szerokim znaczeniu jako określenie poglądów na świat oraz życie ludzkie, które preferuje określona grupa ludzka. Pojęcie ,ideologia” zostało wypracowane w okresie rewolucji francuskiej (1789), w kontekście przemian kulturowo-społecznych, a upowszechniono je w naukach społecznych głównie pod wpływem marksizmu (Hidalgo, 2020; Klimczuk, 2010). Od XIX wieku jest to jedno z podstawowych pojęć politycznych i socjologicznych, dotyczące przekonań ludzkich, bazujących na zasadzie realności, a faktycznie zabiegających o subiektywne interesy (Klimczuk, 2010; Nowak, 2002). W wąskim rozumieniu obejmuje zaś ona doktrynę, która zawiera poglądy dotyczące aktualnej sytuacji ekonomicznej, społecznej i politycznej danego społeczeństwa. To właśnie w nawiązaniu do tych poglądów i w oparciu o nie, wykształca się konkretny program polityczny, który wskazuje, w jaki sposób należy realizować w danym czasie i określonej przestrzeni interes grupy społecznej, która identyfikuje się z daną ideologią (Sołtys, 2015).

W odniesieniu do populizmu ideologia rozumiana jest jako konceptualna mapa świata politycznego (Freeden, 1996; Canovan, 2002) i w ramach tego nurtu populizm rozpatrywany jest jako ,ideologia o cienkim rdzeniu” (ang. thin-centred ideology) (Mudde, 2004; Mudde, Kaltwasser, 2011, 2017; zob. także: Hawkins, Kaltwasser, 2017, 2019; Stanley, 2008; Albertazzi, McDonnell, 2008a, 2008b; Lipiński, 2020a, b; Neuner, Wratil, 2020; Seongcheol, Aristotelis, 2020). Powyższe stwierdzenie pochodzi z badań M. Freeden, który wyróżnił ją tuż obok ,pełnych ideologii”, uwzględniających wszystkie główne kategorie polityczne oraz mających ambicje odpowiedzi na kluczowe pytania, dotyczące wspólnoty politycznej (Freeden, 1996, 1998, 2003). „Ideologia o cienkim rdzeniu” ma natomiast proporcjonalnie odwrotną strukturę morfologiczną, tzn. ogranicza się do niewielu pojęć, stanowiących jej rdzeń, a które są wyraźnie skoncentrowane wokół wybranych problemów i pytań (Lipiński, 2020a, b). W tym sensie populizm opiera się na kilku podstawowych kategoriach, które wchodzą $\mathrm{w}$ interakcje $\mathrm{z}$ innymi ideologiami i zawsze występują w jakiejś kombinacji z nimi, np. z nacjonalizmem, ksenofobią, fundamentalizmem (Taggart, 2004, Stanley, 2008; Mudde, Kaltwasser, 2011).

Właśnie takie rozumienie ideologii stało się podwaliną definicji populizmu C. Mudde (2004, s. 543). Określa się go jako „ideologię, która zakłada, że społeczeństwo jest podzielone na dwie jednorodne, antagonistyczne grupy, «czysty lud» i «skorumpowaną elitę», i która głosi, że polityka powinna być wyrazem volonté générale lub ogólnej woli ludu". Wskazana tu definicja zwraca uwagę na dwie zasadnicze części składowe populizmu: lud jako suweren w odniesieniu do wszelkich działań i rozstrzygnięć politycznych oraz antyelitaryzm (Bakker i in., 2015; Rooduijn, 2013; Mudde, Kaltwasser, 2017). Można zatem powiedzieć, że populizm jest antyelitarny, ponieważ oskarża elitę o podejmowanie działań sprzecznych z wolą ludu (Mény, Surel, 2002). 
Obok zarysowanej wertykalnej orientacji populizmu wobec elit, należy także wskazać na fakt, że populizm na poziomie horyzontalnym stoi w opozycji do osób i grup, których przynależność do ludu jest w oczach populistów fundamentalnie sporna, np. mniejszości seksualne lub etniczne, imigranci (Rensmann, 2006). W tym kontekście można wyróżnić pewne charakterystyczne cechy populizmu jako ,ideologii o cienkim rdzeniu”, do których należy sześć odrębnych, jednak wzajemnie powiązanych ze sobą elementów: 1) istnienie dwóch homogenicznych jednostek analizy: ludu oraz elity; 2) antagonistyczna relacja pomiędzy ludem a elitą; 3) idea suwerenności ludu; 4) pozytywna ocena ludu oraz negatywna ocena elity; 5) afirmacja własnej kultury oraz wykluczenie ,innego"; 6) jedność populistycznego lidera z ludem (Stanley, 2008; Albertazzi, McDonnell, 2008a, b, 2015; Aslanidis, 2016; Lipiński, 2020a).

Populistyczna ,ideologia o cienkim rdzeniu” pojawia się zawsze tam, gdzie w sensie egzystencjalnym ludzie posiadają poczucie zagubienia lub zagrożenia, gdy myślą, że są przegrani i że wszystko wskazuje na to, że ich osobiste marzenia, plany, korzyści, stanowiska, różnego rodzaju przywileje prywatnego życia, ale także grupowe interesy, mogą zostać przejściowo lub trwale utracone. Takie myślenie wzmacnia kryzys strukturalny, gdy konkretni ludzie czują się ignorowani przez globalne systemy polityczne, ekonomiczne lub gospodarcze. W efekcie wspomniane poczucie zagrożenia prowadzi do pewnego rodzaju nostalgii za bliżej nieokreśloną i często wyimaginowaną przeszłością, a także do tego, że społeczeństwa zamykają się w obronie przed ludźmi szukającymi azylu i pomocy, zaś życie prywatne i publiczne wypełnia poczucie krzywdy i niesprawiedliwości. Wskazany tu kontekst społeczno-polityczny stanowi podatny grunt dla populistów. To właśnie wówczas pojawiają się najczęściej „,populistyczni wybawcy”, którzy w imię zasady „,dziel i rządź" umiejętnie wykorzystują pragnienia i tęsknoty obywateli. Ich pełnym manipulacji działaniom przyświeca zasadniczy cel: wskrzeszenie myśli o złotej przeszłości w imię bodowy nowej złotej przyszłości, w której status quo zwykłych ludzi nie jest i nigdy nie będzie kwestionowane. W takiej sytuacji tożsamość, religia i kultura zostają sprowadzone do roli emocjonalnych probierzy (Courau, Babić, 2019).

\section{Ideologiczne zawłaszczanie religii przez populistów: judaizm, chrześcijaństwo, islam}

Religia jest potrzebna populistom przede wszystkim do tego, aby zapewnić skuteczne oddziaływanie na umysły i serca obywateli (Steinmetz-Jenkins, Jäger, 2019). W ich rękach staje się ona źródłem wąsko rozumianej tradycji, stabilności i tożsamości. To pozwala populistycznym przywódcom konstruować programowe hasła, w oparciu o selektywny dobór treści oraz permanentne eliminowanie wszystkiego, co sprzyjałoby pokojowemu współżyciu obywateli oraz ładowi społecznemu w liberalnych demokracjach (Courau, Babić, 2019; Orth, Resing, 2017; Lesch, 2017). Właśnie wspomniane tu ideologiczne zawłaszczanie religii przez populistów stanowi jedną z kluczowych relacji pomiędzy tymi dwoma zjawiskami (Herbst, Menne, 2020; Heimbach-Steins i in., 2019; Kubik, Moos, 2019). Jest to relacja tak złożona, że niektórzy badacze charakteryzują ją jako wręcz tzw. ,religijny populizm” (Herbst, Menne, 2020; Mabille, 2019), nastręczający wielu trudności, gdyż motywy populistów nie są łatwe do rozszyfrowania (Gmainer- 
-Pranzl, 2019; Herbst, Menne, 2020). Populiści w Europie, zarówno w odniesieniu do społeczno-kulturowych i religijnych uwarunkowań, w perspektywie historycznej (zob. m.in.: Zander, 2016; Haupt, Langewiesche, 2004; Elsas, 2002), jak i we współczesnej (zob. m.in.: Liedhegener, Odermatt, 2014, 2017, 2018; Appel i in., 2012), próbują przede wszystkim zawłaszczać do realizacji swoich celów trzy wielkie religie monoteistyczne: islam, judaizm i chrześcijaństwo (Wiedemann, 2016).

\section{a) Judaizm}

Ważne miejsce w ramach ideologicznej działalności partii populistycznych (przede wszystkim prawicowych) odgrywa podejście do judaizmu. Związek, który zachodzi pomiędzy judaizmem a populizmem, jest złożony, ponieważ odnosi się nie tylko do rozmienia Izraela jako ekskluzywnej ojczyzny Żydów, ale także przejawia się w absolutyzacji relacji zachodzących pomiędzy judaizmem jako religią - szczególnie jego ortodoksyjnym nurtem, a samym narodem żydowskim (Filc, 2016).

Złożone relacje pomiędzy populizmem i judaizmem uwidaczniają się przede wszystkim w postulatach i działaniach izraelskiej partii politycznej Szas², która jest orędowniczką sefardyjskiej ludności Izraela i państwa rządzonego przez żydowskie prawo religijne (Zúquete, 2017). Populiści używają judaizmu do wyznaczania granic narodowości i potęgowania nacjonalizmu w taki sposób, aby całkowicie wykluczyć obywateli, którzy nie są izraelskimi Żydami (Filc, 2016; Yilmaz, Morieson, 2021). Poza tym w populistycznej optyce judaizm stanowi czynnik niezbędny do konstytuowania narodowej lojalności, pozwalającej na oddzielenie autentycznych członków narodu od nielojalnych elit i kosmopolitów (Ben Porat, Filc, 2020).

Warto jest w tym miejscu wskazać także, za F. Wiedemann (2016), na dwojaką relację, która charakteryzuje podejście populistów do judaizmu i przybiera wobec niego wrogi charakter.

Po pierwsze, trzeba rozróżnić wrogość religijną wobec Żydów w węższym znaczeniu, to znaczy jako antysemityzm (Wodak, 2018; Erb, Kohlstruck, 2016; Botsch, Kopke, 2016; Beauzamy, 2013; Bachner, 2013). Antysemityzm, a więc antyżydowskie stereotypy, uprzedzenia i urazy są bardzo elastyczne i od dwóch tysięcy lat dostosowują się do nowych wydarzeń społeczno-politycznych (Wodak, 2018; Wetzela, 2014). Populiści wykorzystują obecnie przede wszystkim fakt, że wielu ludzi na świecie podziela antysemiscki obraz Żydów, utożsamiając ich z elitą, a więc jako ludzi bogatych, uprzywilejowanych, kosmopolitycznych i wpływowych (Wodak, 2018).

Po drugie, zdaniem F. Wiedemanna, główną rolę dla populistów odgrywa inny faktor, którym jest religijny wariant w podejściu do judaizmu. Chodzi o taką formę antysemityzmu, „która jest skierowana przeciwko religii chrześcijańskiej jako kontynuacji samego judaizmu [...]" (Wiedemann, 2016, s. 519). W tym podstawowym ujęciu można wyróżnić dwa warianty antychrześcijańskiego antysemityzmu, do których należy:

1) argumentacja „romantyczna”, polegająca na potęgowaniu oskarżenia, że monoteizm

biblijny odrywa ludzi od ich naturalnego porządku i ich relacji do rodzimych, natu-

${ }^{2}$ Szczegółowych informacji o partii Szas i jej wpływie na współczesny Izrael dostarcza opracowanie M. Szydzisza i P. Pokrzywińskiego (2018). 
ralnych bóstw. Populiści chcą $\mathrm{w}$ ten sposób obarczyć winą tradycję judeochrześcijańską za wyobcowania współczesnego człowieka od natury oraz skłonienie go do działalność na szkodę środowiska naturalnego (Wiedemann, 2010, 2016);

2) argumentacja „racjonalistyczna” opiera się na szukaniu w historii Kościoła takich wydarzeń i zjawisk, które mogą być interpretowane jako negatywne dla jego starotestamentalnych fundamentów. W takim ujęciu populiści ukazują judaizm jako religię ślepego i niewolniczego posłuszeństwa, sztywnych reguł, fanatyzmu, archaizmu i wielorakich przesądów (Wiedemann, 2010, 2016). „Do tego obszaru należą odniesienia do »Boga zemsty« w Starym Testamencie, a także obecne przede wszystkim w tekstach kobiet skrajnej prawicy ślady przypisania źródeł zachodniej mizoginii "patriarchatowi żydowskiemu«" (Wiedemann, 2016, s. 520).

Powyższe dwa warianty antychrześcijańskiego antysemityzmu pozwalają wyciągnąć wniosek, że antychrześcijański antysemityzm to, w najprostszym ujęciu, nic innego jak propagowany przez populistów antymonoteizm. W populistycznej wizji opiera się przede wszystkim na dualizmie transcendencji i immanencji, zbezczeszczeniu świata i wyzwolenia człowieka od natury, a także na uniwersalizmie etycznym i wyraźnym oddzieleniu zbawienia od wszelkich przejawów ziemskiego funkcjonowania (Wiedemann, 2016).

\section{b) Chrześcijaństwo}

Chrześcijaństwo, głęboko zakorzenione w judaizmie (Wolffsohn, 2008), jest również wykorzystywane przez populistów do ich złożonej gry politycznej i relacja ta bynajmniej nie jest jednolita (Wiedemann, 2016). Z roku na rok można znaleźć coraz więcej informacji o działaniach prawicowych partii populistycznych w kontekście nadużywania chrześcijańskich treści, terminów, przekonań, wartości lub symboli (Becker, 2018). W debacie naukowej dotyczącej tego zagadnienia tematycznego krążą obecnie dwie - pozornie konkurujące ze sobą - tezy (Hidalgo, Yendell, 2019).

Po pierwsze, podkreśla się za N. D. Marzouki, D. McDonnell i O. Roy (2016), że populiści porywają i zawłaszczają religię. Takie stwierdzenie opiera się na fakcie, że partie populistyczne instrumentalizują lub często też fałszują treści religijne na rzecz własnego programu politycznego. Chrześcijaństwo pełni dla populistów rolę niejako „obrońcy Zachodu” przed imigracją „niebezpiecznych” innowierców i jest w ten sposób degradowane do poziomu religii kulturowej (Hidalgo, Yendell, 2019). Po drugie, doktryny religijne i populistyczne ścierają się i przenikają dogłębnie na płaszczyźnie autorytaryzmu społeczno-kulturowego, „który charakteryzuje się przede wszystkim ostrą retoryką Law \& Order, antypluralistyczną polityką wobec mniejszości (religijnych) i niezwykle konserwatywnym wizerunkiem rodziny. Zwłaszcza jeśli chodzi o kwestie takie, jak odrzucenie gender mainstreaming, walka $\mathrm{z}$ aborcją $\mathrm{i}$ tym podobne, religijni i prawicowi aktorzy populistyczni często łączą siły [...]" (Hidalgo, Yendell 2019, s. 1).

Interesujący model, wyjaśniający powiązania, zachodzące między religią chrześcijańską a populizmem, prezentuje w swoim artykule H. Rebenstorf (2018), powołując się na przeprowadzone w latach sześćdziesiątych przez Gordon W. Allport'a badania, dotyczące religijnego kontekstu uprzedzeń w USA (Allport, 1966). Jego studia wykazały, że 
osoby często uczestniczące w praktykach religijnych, były bardziej podatne na uprzedzenia rasistowskie, etniczne i religijne niż osoby niechodzące do kościoła. Z drugiej zaś strony to chrześcijaństwo, w ujęciu historycznym, było niejednokrotnie motorem napędowym do walki o prawa obywatelskie, tolerancję czy solidarność lub sprawiedliwość społeczną (Allport, 1966, Allport, Ross, 1967). Zdaniem H. Rebenstorf (2018) jest to sytuacja co najmniej paradoksalna, której zrozumienie możliwe jest poprzez uświadomienie sobie trzech kontekstów, w których niejako funkcjonuje religia: społeczno-kulturowym, osobowościowo-psychologicznym i teologicznym.

Kontekst społeczno-kulturowy wskazuje przede wszystkim na fakt, że religie dostosowują się do społecznych, narodowych, etnicznych czy też strukturalnych napięć, mających miejsce w danych krajach (Rebenstorf, 2018; Küpper, Zick, 2016). Kontekst osobowościowo-psychologiczny wpływa natomiast na poziom znaczenia religii, przekonań i praktyk religijnych $\mathrm{w}$ osobistym życiu jednostki: może mieć charakter religijności zewnętrznej (utylitarnej) lub wewnętrznej (wiara jako wartość sama w sobie) (Rebenstorf, 2018; Allport, 1966; Allport, Ross, 1967). Ostatni kontekst, teologiczny, związany jest z doktryną religijną, na pierwszy rzut oka zbudowaną wokół nauczania o miłości bliźniego, ale zarazem zawierającą niejako trzy katalizatory w odniesieniu do postaw populistycznych, antyspołecznych i faszystowskich: 1) doktryna objawienia i związane z nią roszczenia do wyłączności na posiadanie prawdy; 2) doktryna wybrania, zakładająca podział na osoby przynależące i nieprzynależące do danej grupy religijnej; 3) kwestia teokracji czy też świeckości państwa (Rebenstorf, 2018).

Warto także zauważyć, że populiści, którzy instrumentalizują chrześcijaństwo, często znajdują się w sprzeczności z instytucjonalnym Kościołem katolickim. Kościół jest dla partii populistycznych np.: we Francji zbyt liberalny w kwestiach imigracji, a jednocześnie, zbyt konserwatywny w kwestii moralności (Roy, 2016a; DeHanas, Shterin, 2018; Brubaker, 2017a, b). W tym sensie religia ma o tyle znacznie, o ile wyznacza zbiorową tożsamość, pozwalającą na uproszczone dychotomie społeczne pomiędzy my (dobrzy) i oni (źli). Tożsamość chrześcijańska ma zatem dwojaki cel, który polega na budowaniu nostalgii za złotą narodową przeszłością i uczynienie z islamu zupełnie obcej i agresywnej kultury (DeHanas, Shterin, 2018; Roy, 2016b; Brubaker, 2017a, b). W swoim własnym postrzeganiu populiści są chrześcijanami tylko w takim stopniu, w jakim są antymuzułmańscy (DeHanas, Shterin, 2018).

\section{c) Islam}

Temat relacji, zachodzących pomiędzy islamem a cienką ideologią populizmu, interesuje badaczy głównie na dwóch płaszczyznach. Po pierwsze, prowadzone są liczne badania dotyczące rozwoju populizmu w krajach, w których większość stanowią muzułmanie (zob. m.in: Schmuck, Tribastone, 2020; Nurjannah i in., 2019; Kirdiş, Drhimeur, 2016; Hadiz, 2013, 2016, 2018). Po drugie - szczególnie w Europie - badacze koncentrują się na rozprzestrzenianiu się antyislamskiej niechęci oraz związanym z tym sukcesie prawicowych partii populistycznych (zob. m.in.: Pickel, Öztürk, 2021; Cervi, 2020; Oztig i in., 2020; Kalmar, 2019; Kaya, Tecmen, 2019; Kortmann i in., 2019; Whi- 
te, 2019; Botsch i in., 2012), ogniskujących się wokół takich toposów, jak: mizoginia, fanatyzm i nietolerancja (Wiedemann, 2016).

Islam i populizm łączą się ze sobą głównie na płaszczyźnie ,islamizmu”, który należy rozumieć jako termin zbiorowy dla wszystkich politycznych kategorii islamu, propagujący absolutny powrót do reguł Koranu i „rządów Boga” (Gesell, 2017; Hirschmann, 2016). Takie podejście pociąga za sobą polityczne cele populistów w krajach muzułmańskich, do których należy m.in.: radykalna rekonstrukcja kultury, społeczeństwa, polityki i państwa, a także dystansowania się od ich najnowszej historii religijnej i politycznej, na którą ma wpływ ,zły” i ,zepsuty” Zachód (Gesell, 2017; Bötticher, Mares, 2012; Hirschmann, 2011). Ów ,zły” i ,zepsuty” Zachód jest jednym z podstawowych elementów retoryki islamistycznej, która kreuje obszerny katalog tzw. obrazów wroga. Wrogiem są nie tylko niewierni, chrześcijanie i Żydzi, ale także liberałowie, Amerykanie, komuniści, socjaliści, rewolucjoniści seksualni, feministki i homoseksualiści (Gesell, 2017; Schmidinger, Dunja, 2012; Bötticher, Mares, 2012). „To spotęgowane skupienie się na serii obrazów wroga ujawnia silną, czarno-białą strukturę myślenia w sensie dualizmu: dobry-zły, w którym własny, wyidealizowany model społeczny, jest pomyślany jako pozytywny odpowiednik rzekomo wrogiego ,amerykańskiego, zachodniego, syjonistycznego projektu" (Gesell, 2017, s. 10).

Jeśli zaś chodzi o niechęć europejskich populistów do religii muzułmanów, to w swojej analizie M. Krzyżanowski (2013) rekonstruuje semantyczne pole islamu, prezentowanego jako zagrożenie. Jego zdaniem obejmuje ono następujące treści: rosnąca liczba muzułmanów w Europie, Koran i nawoływanie do przemocy, radykalna edukacja islamska, minarety jako symbol muzułmańskiej przemocy, nierespektowanie praw kobiet, nadużywanie wolności religijnej przez muzułmanów (Krzyżanowski, 2013; Lesch, 2020). Tak rozumiany negatywny stosunek do islamu i obecności muzułmanów w Europie, przecina nie tylko całe spektrum polityczne oraz zaburza w ten sposób mapę standardowych podziałów na lewicę i prawicę (Starnawski, 2017; Bobako, 2012/2013), ale także - jak w przypadku populistycznej retoryki islamistycznej - implikuje podziała świata na „dobry” i ,zły”. W takim ujęciu ,zły” jest islam, któremu przeciwstawiony jest Zachód, prezentowany jako „dobry”. Zachód to ostoja demokracji, praw człowieka i cywilizacji, zaś islam to religia fanatyczna, dogmatyczna, agresywna i uciskająca kobiety (Molo, 2011). Uprzedzenia i stereotypy, funkcjonujące na temat islamu i muzułmanów, są instrumentalnie wykorzystywane przez populistyczne ruchy czy partie w Europie. Islamofobia staje się więc przydatna dla populizmu jako treść, polityczna taktyka i środek komunikowania się (Molo, 2011; Meyer, Schubert, 2011; Ruf, 2010; Schneiders, 2009; Häusler, 2008).

\section{„Punkt styczny": upolitycznienie religii i sakralizacja polityki}

W ogólnym ujęciu można konkludować, że współczesny związek między populizmem a wiodącymi religiami monoteistycznymi posiada wspólny ,punkt styczny”, którym jest upolitycznienie religii lub sakralizacja polityki (Mancini, Rosenfeld, 2020).

Upolitycznienie religii prowadzi do sytuacji, w której tożsamość i cele polityczne są kształtowane w oparciu o doktrynę religijną. Taki stan rzeczy ma przede wszyst- 
kim doprowadzić do wprowadzenia podziałów społecznych pomiędzy wyznawcami wiodącej religii oraz osobami, które znajdują się poza spektrum jej wpływów, np.: niewierzący, agnostycy, wyznawcy innych religii. Osoby niezwiązane z wiodącą religią są wówczas uważane za wrogów danej populacji (Zúquete, 2017; Mancini, Rosenfeld, 2020), a nawet za „barbarzyńców”, przed którymi trzeba się bronić (DeHanas, Shterin, 2018). W pewnym sensie $\mathrm{w}$ doktrynie populistycznej ścierają się $\mathrm{w}$ tym miejscu elementy religijne z elementami nacjonalistycznymi, sprowadzającymi naród do monolitu kulturowo-religijnego. Pewien stopień homogeniczności religijnej może służyć zapobieganiu rozpadowi i asymilacji danego narodu lub też wpływać na proces budowania lub rekonstrukcji narodu, zgodnie z ukrytymi i domyślnie przyjętymi przez populistów zasadami religijnymi (Molle, 2018). Populiści, aby zapewnić względną jedność narodu, powstają zarówno przeciwko wrogom wewnętrznym, np. elita, jak i zewnętrznym, np. inne narody (Mancini, Rosenfeld, 2020).

Należy również pamiętać, że upolitycznienie religii ma ścisły związek ze zjawiskiem jej instrumentalizacji. W tym kontekście B. Welte wskazał na cztery główne formy ideologizowania religii: 1) ideologizacja poprzez społeczną instrumentalizację; 2) ideologizacja poprzez absolutyzowanie człowieka; 3) ideologizacja estetyczna; 4) ideologizacja ze względu na prestiż (Welte, 1980). A. Sołtys (2015) zauważa, że spośród powyższych form to instrumentalizacja religii jest najbardziej niebezpieczna, ponieważ posługuje się religią w celu zdobycia władzy nad ludźmi i jej utrzymaniu. W tym sensie religia staje się nie tylko instrumentem w rękach polityków, ale także swego rodzaju fasadą, zasłaniającą mało szlachetne cele, do których dążą populistyczni politycy (Sołtys, 2015).

Drugi ,punkt styczny” to sakralizacja polityki, mająca na celu stworzenie wokół działalności politycznej swoistej osnowy religijnej, poprzez wskazywanie na liczne analogie pomiędzy religią a polityką, np.: przywódca polityczny przyjmuję rolę charyzmatycznego duchownego, który wiedzie lud do „ziemi obiecanej”; zwolennicy to przedstawiciele dobra, zaś przeciwników utożsami się ze złem (Zúquete, 2017; Mancini, Rosenfeld, 2020). Polityka nabiera tu transcendentnego charakteru i nie jest rozumiana jako coś przyziemnego i na ludzki sposób ograniczonego, ale jako narzędzie umożliwiające absolutną zamianę poprzez jej zakotwiczenie w religijnych mitach, obrzędach i symbolach, które pobudzają solidarność grupową i nadają ostateczny sens życiu osobistemu i przeznaczeniu całych społeczności. W żaden sposób nie można oddzielić sakralizacji polityki od trendów sekularyzacyjnych i racjonalizacji ludzkiego życia z początku XX wieku, które przyczyniły się do tego, że powstała na ich skutek ,duchowa próżnia”, była okresowo wypełniana ideologiami - głównie faszyzmem, komunizmem i nazizmem. Ich celem było stworzenie nieba na ziemi, a zatem przeniesienie sacrum ze sfery religijnej do świata i nadanie duchowego przewodnictwa i znaczenia kondycji ludzkiej (Zúquete, 2017; Gentile, 2006).

Zdaniem J. P. Zúquete polityczną metamorfozę sacrum należy postrzegać w sposób bardziej ekspansywny, ponieważ wymiar religijnego populizmu zapewnia intymną relację ze świętością: „lud zostaje przemieniony i konsekrowany, jego wrogowie są zwalczani jako ucieleśnienie zła na ziemi, a polityka jest interpretowana, doświadczana i odczuwana jako sprawa transcendentalna" (Zúquete, 2017, s. 9). 


\section{Podsumowanie}

Dokonując podsumowania należy zauważyć, że populizm w odniesieniu do wiodących religii może przyjąć formę jawnie religijną (w postaci upolitycznionej religii) lub formę bardziej subtelną, związaną z sakralizacją polityki (Zúquete, 2017). To nic innego, jak właśnie zawłaszczanie przez populistów treści i symboli religijnych, jest swoistą bazą do budowania „bezbożnego sojuszu” pomiędzy „cienką ideologią” populizmu a judaizmem, chrześcijaństwem i islamem. Wszędzie tam, gdzie populiści dążą do pogłębiania w społeczeństwie postaw antyimigranckich, dewaluacji innych grup społecznych, antyestablishmentu i antypluralizmu, sięgają po religię jako źródło wzmocnienia prezentowanej przez siebie ideologii. Trzeba jednak pamiętać, że z czasem linia podziału między powiązanymi z populizmem zjawiskami marginalizującymi, etnocentrycznymi i ksenofobicznymi a religią, staje się płynna i często trudno ją precyzyjnie zdefiniować (Pickel, 2018). Centralne znaczenie mają tu różnorodne namiętności, leżące u podstaw kształtowania tożsamości politycznych. Jest to o tyle istotne, że populizm stanowi siłę społecznej mobilizacji opartą o niematerialne, kulturowo-religijne i symboliczne elementy, a także o pragnienia, oczekiwania i transcendentną nadzieję na lepszą i bardziej satysfakcjonującą egzystencję w przyszłości „zwykłych” ludzi (Zúquete, 2017).

Wydaje się, że jedynym możliwym wyjściem z populistycznego impasu współczesności jest przede wszystkim i ponad wszystko polityczna, a także międzyreligijna edukacja i wychowanie, które będą kształtować nie tylko ludzi wierzących, ale i obywateli otwartych na inne religie i światopoglądy, gotowych do dialogu międzyreligijnego, akceptujących pluralizm i zdolnych do krytycznej refleksji wobec populistycznych treści i manipulacji. W tym sensie, jak zauważa papież Franciszek w encyklice „Fratelli tutti” (dotyczącej braterstwa i przyjaźni społecznej), to właśnie obowiązek edukacji, „obowiązek wychowania, rozwój nawyków solidarności, zdolność do myślenia o życiu ludzkim w sposób bardziej integralny oraz duchowa głębia są konieczne, aby podnieść jakość relacji ludzkich tak, aby samo społeczeństwo reagowało na istniejące w nim nierówności, wynaturzenia i nadużycia ze strony sił gospodarczych, technologicznych, politycznych i medialnych" (Franciszek, 2020, nr 167).

\section{Bibliografia}

Albertazzi D., McDonnell D. (2008a), Introduction: The sceptre and the spectre, w: Twenty-first century populism: The spectre of western European democracy, red. D. Albertazzi, D. McDonnell, Palgrave, Basingstoke.

Albertazzi D., McDonnell D. (2008b), Twenty-first century populism: The spectre of western European democracy, Palgrave, Basingstoke.

Albertazzi D., McDonnell D. (2015), Populists in power, Routledge, London-New York.

Allport G. W. (1966), The religious contest of prejudice, „Journal for the scientific study of religion”, vol. $5, \mathrm{nr} 3$.

Allport G. W., Ross J. M. (1967), Personal religious orientation and prejudice, „Journal of personality and social psychology", vol. 5, nr 4.

Appel K., Danz Ch., Potz R., Rosenberger S., Walser A. (2012), Religion in Europa heute Sozialwissenschaftliche, rechtswissenschaftliche und hermeneutisch-religionsphilosophische Perspektiven, V\&R unipress, Göttingen. 
Aslanidis P. (2016), Is populism an ideology? A refutation and a new perspective, „Political Studies”, vol. 64 .

Avgoulas M. I., Fanany R. (2012), Religion as a Source of Resilience for Elderly Greeks in Melbourne, Australia, https://www.atiner.gr/papers/PSY2012-0089.pdf, 12.02.2021.

Bachner H. (2013), Notions of Jewish Power, Manipulation and Conspiracies in Contemporary Antisemitism in Sweden, https://archive.jpr.org.uk/object-756, 2.02.2021.

Bakker B., Rooduijn M., Schumacher G. (2016), The Psychological Roots of Populist Voting: Evidence from the United States, the Netherlands and Germany, „European Journal of Political Research", vol. 55, nr 2.

Beauzamy B. (2013), Continuities of Fascist Discourses, Discontinuities of Extreme-Right Political Actors? Overt and Covert Antisemitism in the Contemporary French Radical Right, w: Analysing Fascist Discourse: European Fascism in Text and Talk, red. R. Wodak, J. E. Richardson, Routledge, London.

Becker G. (2018), Rechtspopulismus und Christentum, http://www.proscientia.at/Datei-Download/402/ Gudrun+BECKER\%2C+Rechtspopulismus+und+Christentum $\% 2 \mathrm{C}+22.10 .2018 \% 2 \mathrm{C}+$ Linz. pdf, 11.01.2020.

Ben Porat, G., Filc D. (2020), Remember to be Jewish: Religious Populism in Israel, https://www.cambridge.org/core/services/aop-cambridge-core/content/view/5EC0AD18B715896EF0CD08AD EEA8DE04/S1755048320000681a.pdf/remember-to-be-jewish-religious-populism-in-israel. pdf, 8.06.2021.

Bobako M. (2012/2013), Islamofobia - między »krytyka religii« a rasizmem kulturowym, „Recykling Idei”, nr 14.

Botsch G., Glöckner O., Kopke Ch., Spieker M. (2012), Islamophobie und Antisemitismus - ein umstrittener Vergleich, De Gruyter, Berlin.

Botsch G., Kopke C. (2016), Antisemitismus ohne Antisemiten?, w: Wut, Verachtung, Abwertung Rechtspopulismus in Deutschland, red. R. Melzer, D. Molthagen, A. Zick, B. Küpper, Friedrich Ebert Stiftung, Berlin.

Bötticher A., Mares M. (2012), Extremismus. Theorien - Konzepte - Formen, De Gruyter, München.

Brubaker R. (2017a), Between Nationalism and Civilizationism: The European Populist Movement in Comparative Perspective, „Ethnic and Racial Studies”, vol. 40, nr 8.

Brubaker R. (2017b), Why Populism?, „Theory and Society”, vol. 46.

Canovan M. (2002), Taking Politics to the People: Populism as the Ideology of Democracy, w: Democracies and the Populist Challenge, red. Y. Mény, Y. Surel, Palgrave, London.

Cervi L. (2020), Exclusionary Populism and Islamophobia: A Comparative Analysis of Italy and Spain, „Religions”, vol. 11(10).

Courau T. M., Abraham S., Babić M. (2019), Populism and Religion, SCM Press, London.

DeHanas D. N., Shterin M. (2018), Religion and the rise of populism, „Religion. State and Society”, vol. 46.

Elsas Ch. (2002), Religionsgeschichte Europas. Religiöses Leben von der Vorgeschichte bis zur Gegenwart, Wissenschaftliche Buchgesellschaft, Darmstadt.

Erb R., Kohlstruck M. (2016), Die Funktionen von Antisemitismus und Fremdenfeindlichkeit für die rechtsextreme Bewegung, w: Strategien der extremen Rechte, red. S. Braun, A. Geisler, M. Gerster, Springer, Wiesbaden.

Filc D. (2016), 'We are the (Chosen) People, you are not' The Case of Shas Populism, w: Saving the People: How Populists Hijack Religion, red. N. Marzouki, D. McDonnell, Hurst and Publishers, London.

Franciszek (2020), „Fratelli Tutti”: Encyklika o braterstwie i przyjaźni społecznej, http://www.vatican. $\mathrm{va} /$ content/francesco/pl/encyclicals/documents/papa-francesco_20201003_enciclica-fratelli-tutti.html, 8.03.2020. 
Freeden M. (1996), Ideologies and political theory. A conceptual approach, Clarendon Press, Oxford. Freeden M. (1998), Is Nationalism a Distinct Ideology?, „Political Ideologies”, vol. 46, nr 4.

Freeden M. (2003), Ideology. A very short introduction, Oxford University Press, Oxford.

Gentile E. (2006), Politics as Religion, Princeton University Press, Princeton.

Gesell M. J. (2017), Islamismus und Nationalpopulismus: Zwei Seiten einer Medaille? Ein methodischer Vergleich, https://www.consulting-plus.de/wp-content/uploads/HA-Gesell-adW-Islamismus-Nationalpopulismus.pdf, 10.01.2021.

Gidron N., Bonikowski B. (2013), Varieties of Populism: Literature Review and Research Agenda, „Weatherhead Working Paper Series”, nr 13-0004.

Gmainer-Pranzl F. (2019), Rechtspopulismus und Katholizität: Eine ekklesiologische Besinnung, „Concilium", $\mathrm{nr} 2$.

Hadiz V. R. (2013), A New Islamic Populism and the Contradictions of Development, „Journal of Contemporary Asia", vol. 44, nr 1.

Hadiz V. R. (2016), Islamic populism in Indonesia and The Middle East, Cambridge University Press, Cambridge.

Hadiz V. R. (2018), Imagine All the People? Mobilising Islamic Populism for Right-Wing Politics in Indonesia, „Journal of Contemporary Asia”, vol. 48, $\mathrm{nr} 4$.

Haggard M. C., Kang L. L., Rowatt W. C., Shen M. J. (2015), Associations Among Religiousness and Community Volunteerism in National Random Samples of American Adults, „Journal of Prevention \& Intervention in the Community", vol. 43, nr 3.

Haupt H. G., Langewiesche D. (2004), Nation und Religion in Europa Mehrkonfessionelle Gesellschaften im 19. und 20. Jahrhundert, Campus-Verlag, Frankfurt am Main.

Häusler A. (2008), Rechtspopulismus als „Bürgerbewegung”: Kampagnen gegen Islam und Moscheebau und kommunale Gegenstrategien, Springer, Wiesbaden.

Hawkins K. A., Kaltwasser C. R. (2019), Introduction. The ideational approach, w: The Ideational Approach to Populism: Concept, Theory, and Analysis, red. K. A. Hawkins, R. E. Carlin, L. Littvay, C. R. Kaltwasser, Routledge, London-New York.

Hawkins K., Kaltwasser C. R. (2017), The ideational approach to populism, „Latin American Research Review", vol. 52, $\mathrm{nr} 4$.

Heimbach-Steins M., Behrensen M., Hennig L. E. (Hrsg.) (2019), Gender - Nation - Religion. Ein internationaler Vergleich von Akteursstrategien und Diskursverflechtungen, Campus-Verlag, Frankfurt am Main.

Herbst J.-H., Menne A. (2020), Vox populi vox dei? Theoretische Anhaltspunkte für religiöse Bildung in populistisch aufgeladenen Zeiten, „,Theo-Web,, vol. 19, nr 2.

Hidalgo O. (2020), Politische Ideologien und Religionen als (normative) Vehikel demokratischer Ordnung?, w: Religion, Ethik und Politik. Politik und Religion, red. S. Hammer, O. Hidalgo, Springer, Wiesbaden.

Hidalgo O., Yendell A. (2019), Religion und Rechtspopulismus, https://www.buergergesellschaft.de/ fileadmin/pdf/gastbeitrag_hidalgo_yendell_190619.pdf, 7.02.2020.

Hirschmann K. (2011), Internationaler Terrorismus: Der Siegeszug der Dschihad-Ideologie, w: Neue Dimensionen internationaler Sicherheitspolitik, red. R. Meier-Walser, A. Wolf, Oldenbourg Verlag, München.

Hirschmann K. (2016), Wie Staaten schwach werden. Fragilität von Staaten als internationale Herausforderung, Bundeszentrale für Politische Bildung, Bonn.

Kalmar I. (2019), The east is just like the west, only more so: Islamophobia and populism in Eastern Germany and the East of the European Union, „Journal of Contemporary European Studies”, vol. 28, nr 1.

Karpiński A. J. (2015), Wstęp do nauk o mądrości. Część pierwsza, Wydawnictwo GSW, Gdańsk. 
Kaya A., Tecmen A. (2019), Europe versus Islam?: Right-Wing Populist Discourse and the Construction of a Civilizational Identity, „The Review of Faith \& International Affairs”, vol. 17, nr 1.

Kirdiş E., Drhimeur A. (2016), The rise of populism? Comparing incumbent pro-Islamic parties in Turkey and Morocco, „Turkish Studies”, vol. 17, nr 4.

Klimczuk Z. (2010), Ideologizacja życia społecznego, „Studia Warmińskie”, vol. 47.

Kortmann M., Stecker Ch., Weiß T. (2019), Filling a Representation Gap? How Populist and Mainstream Parties Address Muslim Immigration and the Role of Islam, „Journal of Representative Democracy", vol. 55, $\mathrm{nr} 4$.

Krzyżanowski M. (2013), From Anti-Immigration and Nationalist Revisionism to Islamophobia: continuities and shifts in recent discourses and patterns of political communication of the Freedom Party of Austria, w: Right wing populism in Europe. Politics and discourse, red. R. Wodak, M. KhosraviNik, B. Mral, Bloomsbury, London.

Kubik A., Moos T. (2019), Editorial. Populismus als Thema der Praktischen Theologie, „Praktische Theologie", vol. 54, nr 2.

Küpper B., Zick A. (2016), Religion und Vorurteile - empirische Zusammenhänge über individuelle Einstellungsmuster, w: Handbuch der Religionen, red. M. Klöcker, U. Twuroschka, OLZOG, München.

Lesch W. (2017), Christentum und Populismus. Klare Fronten?, Herder-Verlag, Freiburg, Basel, Wien.

Lesch W. (2020), Visible Religion and Populism: An Explosive Cocktail, „Religions”, vol. 11(8).

Liedhegener A., Odermatt A. (2014), Religionszugehörigkeit in Europa - empirisch: Die Swiss Metadatabase of Religious Affiliation in Europe (SMRE), https://www.smre-data.ch/en/content/ download/58, 6.03.2021.

Liedhegener A., Odermatt A. (2017), Umstrittene Religionszugehörigkeit: Europas religiöse Pluralität zwischen vertrauten Kategorien und neuen religiösen Identitäten, w: Religiöse Identitäten und gesellschaftliche Integration, red. E. Arens, M. Baumann, A. Liedhegener, W. W. Müller, M. Ries, Nomos-Verlag, Baden-Baden-Zurich.

Liedhegener A., Odermatt A. (2018), Religious Affiliation as a Baseline for Religious Diversity in Contemporary Europe. Making Sense of Numbers, Wordings, and Cultural Meanings, https://www. smre-data.ch/en/content/download/159, 10.02.2021.

Lipiński A. (2020a), W poszukiwaniu ontologii populizmu - dylematy definicyjne, „Przegląd Politologiczny", $\mathrm{nr} 1$.

Lipiński A. (2020b), Podejścia jakościowe w badaniach nad populizmem: analiza ideologii, teoria dyskursu i podejście dyskursywno-historyczne, w: Badania nad dyskursem populistycznym: wybrane podejścia, A. Stępińska, A. Lipiński, Uniwersytet im. Adama Mickiewicza w Poznaniu Wydawnictwo Naukowe Wydziału Nauk Politycznych i Dziennikarstwa, Poznań.

Mabille F. (2019), Religious Populism: the New Avatar of Political Crisis, „Concilium”, nr 2.

Mancini S., Rosenfeld M. (2020), Nationalism, Populism, Religion, and the Quest to Reframe Fundamental Rights, https://papers.ssrn.com/sol3/Delivery.cfm/SSRN_ID3677401_code1717611. pdf?abstractid $=3677401 \&$ mirid $=1,5.02 .2021$.

Marczewska-Rytko M. (2011), Teoretyczne aspekty wspótczesnego populizmu, „Krakowskie Studia Międzynarodowe", vol. 8, $\mathrm{nr} 4$.

Marzouki N. D, McDonnell D., Roy O. (2016), Saving the People: How Populists Hijack Religion, Hurst \& Company, London.

Mény Y., Surel Y. (2002), The Constitutive Ambiguity of Populism, w: Democracies and the Populist Challenge, red. Y. Mény, Y. Surel, Palgrave, New York.

Meyer H., Schubert K. (2011), Politik und Islam, Springer, Wiesbaden.

Molle A. (2018), Religion and right-wing populism in Italy: using "Judeo-Christian roots" to kill the European Union, „Religion, State and Society”, vol. 47. 
Molo B. (2011), Niemcy między populizmem a islamofobia, „Krakowskie Studia Międzynarodowe”, nr 4.

Mudde C. (2004), The Populist Zeitgeist. Government and Opposition, vol. 39, nr 4.

Mudde C., Kaltwasser C. R. (2011), Voices of the peoples: populism in Europe and Latin America compared, https://kellogg.nd.edu/publications/workingpapers/WPS/378.pdf, 24.11.2020.

Mudde C., Kaltwasser R. (2017), Populism. A Very Short Introduction, Oxford University Press, Oxford.

Neuner F. G., Wratil, C. (2020), The Populist Marketplace: Unpacking the Role of "Thin" and "Thick" Ideology, „Political Behavior”, nr 3.

Nowak A. J. (2002), Ideologia, w: Leksykon duchowości katolickiej, red. M. Chmielewski, Wydawnictwo „M”, Lublin-Kraków.

Nurjannah S., Khudzaifah D., Bambang S., Mu'inudillah B. (2019), The Resurgence of Islamic Populist: Purification Understanding of Usury Banking in X-Banker Community-Indonesia, „Journal of Advanced Research in Dynamical and Control Systems", vol. 11, $\mathrm{nr} 8$.

Orth S., Resing V. (2017), AfD, Pegida und Co. Angriff auf die Religion?, Herder, Freiburg im Breisgau.

Oztig L. I., Gurkan T. A., Aydin K. (2020), The Strategic Logic of Islamophobic Populism, „Government and Opposition", vol. 19, nr 1.

Palaver W. (2018), Populism und Religion angesichts einer Politik der Angst, „Salzburger Theologische Zeitschrift", vol. 23, nr 2.

Palaver W. (2019), Populism and religion: On the politics of fear, „Dialog: A Journal of Theology”, vol. $58, \mathrm{nr} 1$.

Pargament K., Feuille M., Burdzy D. (2011), The Brief RCOPE: Current Psychometric Status of a Short Measure of Religious Coping, „Religions”, vol. 2.

Pargament K. I., Cummings J. (2010), Anchored by Faith: Religion as a Resilience Factor, w: Handbook of Adult Resilience, red. J. W. Reich, A. J. Zautra, J. S. Hall, The Guilford Press, New York-London.

Pickel G. (2018), Religion als Ressource für Rechtspopulismus? Zwischen Wahlverwandtschaften und Fremdzuschreibungen, „Zeitschrift für Religion, Gesellschaft und Politik”, vol. 2.

Pickel G., Öztürk C. (2021), The Varying Challenge of Islamophobia for the EU: On Anti-Muslim Resentments and Its Dividend for Right-Wing Populists and Eurosceptics - Central and Eastern Europe in a Comparative Perspective, w: Illiberal Trends and Anti-EU Politics in East Central Europe, Palgrave Studies in European Union Politics, red. A. Lorenz, L. H. Anders, Palgrave, Cham.

Prado G., Feaster D. J., Schwartz S. J., Pratt I. A., Smith L., Szapocznik J. (2004), Religious Involvement, Coping, Social Support, and Psychological Distress in HIV-Seropositive African American Mothers, „AIDS and Behavior”, vol. 8, nr 3.

Putnam R. D., Campbell D. E. (2012), American grace: How religion divides and unites us, Simon and Schuster, New York.

Rebenstorf H. (2018), ,,Rechte“ Christen? - Empirische Analysen zur Affinität christlich-religiöser und rechtspopulistischer Positionen, „Zeitschrift Für Religion, Gesellschaft und Politik”, vol. 2, $\mathrm{nr} 2$.

Rensmann L. (2006), Populismus und Ideologie, w: Populismus: Gefahr für die Demokratie oder nützliches Korrektiv?, red. F. Decker, Springer, Wiesbaden.

Rooduijn M. (2013), The mesmerising message: The diffusion of populism in public debates in western European media, „Political Studies”, vol. 62, nr 4.

Roy O. (2016a), The French National Front: From Christian Identity to Laicité, w: Saving the People: How Populists Hijack Religion, red. N. Marzouki, D. McDonnell, Hurst and Publishers, London. 
Roy O. (2016b), Beyond Populism: The Conservative Right, the Courts, the Churches and the Concept of a Christian Europe, w: Saving the People: How Populists Hijack Religion, red. N. Marzouki, D. McDonnell, Hurst and Publishers, London.

Ruf W. (2010), Muslime in den internationalen Beziehungen - das neue Feindbild, Springer, Wiesbaden.

Saroglou V., Corneille O., Van Cappellen P. (2009), "Speak, Lord, your servant is listening": Religious priming activates submissive thoughts and behaviors, ,International Journal for the Psychology of Religion", vol. 19, nr 3.

Saroglou V., Pichon I., Trompette L., Verschueren M., Dernelle R. (2005), Prosocial behavior and religion: New evidence based on projective measures and peer ratings, „Journal for the Scientific Study of Religion", vol. 44, nr 3.

Schmidinger T., Dunja L. (2012), Ideologeme des politischen Islam, w: Zwischen Gottesstaat und Demokratie. Handbuch des politischen Islam, red. L. Dunja, T. Schmidinger, Zsolnay, Wien.

Schmuck D., Tribastone M. (2020), Muslims Take Action. How Exposure to Anti-Islamic Populist Political Messages Affects Young Muslims'Support for Collective Action: A Longitudinal Experiment, „Political Communication”, vol. 37.

Schneiders T. G. (2009), Islamfeindlichkeit. Wenn die Grenzen der Kritik verschwimmen, Springer, Wiesbaden.

Seongcheol K., Aristotelis A. (2020), Populismus, Diskurs, Staat. Eine konzeptuelle Einführung in die Populismusforschung, w: Populismus, Diskurs, Staat, red. K. Seongcheol, A. Agridopoulos, Nomos-Verlag, Baden-Baden.

Sołtys A. (2015), Polityczna ideologizacja religii zagrożeniem bezpieczeństwa państw w obszarze basenu morza śródziemnego, „Teka Komisji Politologii i Stosunków Międzynarodowych”, vol. 10, nr 2 .

Stanley B. (2008), The thin ideology of populism, „Journal of Political Ideologies”, nr 13.

Starnawski M. (2017), Populizm antyislamski a socjalizacja polityczna w kontekście polskim, „Praktyka Teoretyczna", vol. 26, nr 4.

Steinmetz-Jenkins D., Jäger A. (2019), The populist right is forging an unholy alliance with religion, https://www.theguardian.com/commentisfree/2019/jun/11/populists-right-unholy-alliance-religion, 25.12.2020.

Surzykiewicz J. (2015), Religia, religijność i duchowość jako zasoby osobowe i kapitat społeczny w pedagogice społecznej/pracy socjalnej, „Pedagogika Społeczna”, vol. 55, nr 1.

Szydzisz M., Pokrzywiński P. (2018), Szas i jego wpływ na współczesny Izrael, w: Wybrane systemy polityczne i partyjne - wyzwania i prognozy, red. K. Kamińska-Korolczuk, M. Mielewczyk, R. Ożarowski, Wydawnictwo Athenae Gedanenses, Gdańsk.

Taggart P. (2004), Populism and representative politics in contemporary Europe, „Journal of Political Ideologies", nr 9.

Welte B. (1980), Ideologie und Religion, w: Christlicher Glaube in moderner Gesellschaft, red. F. Böckle, F-X. Kaufmann, K. Rahner, B. Welte, t. 21, Herder, Freiburg.

White D. E. (2019), Christianity, Islam, and the UK Independence Party: Religion and British Identity in the Discourse of Right-Wing Populists, „Journal of Church and State”, vol. 61, nr 3.

Wiedemann F. (2010), »...verbrannt auf dem Holzstoße Jahwe zu Ehren " - Antichristlicher Antisemitismus in neuheidnischen Hexenbildern, w: Politik des Hasses. Antisemitismus und radikale Rechte in Europa, red. G. Botsch, Ch. Kopke, L. Rensmann, J. H. Schoeps, Olms, Hildesheim.

Wiedemann F. (2016), Das Verhältnis der extremen Rechten zur Religion, w: Handbuch Rechtsextremismus, Edition Rechtsextremismus, red. F. Virchow, M. Langebach, A. Häusler, Springer, Wiesbaden.

Wodak R. (2018), The radical right and antisemitism, w: The Oxford Handbook of the Radical Right, red. J. Rydgren, Oxford University Press, Oxford. 
Wolffsohn M. (2008), Juden und Christen - ungleiche Geschwister. Die Geschichte zweier Rivalen, Patmos Verlag, Düsseldorf.

Yilmaz I., Morieson N. (2021), Different ways in which religion and populism intersect within world's great faiths, https://www.populismstudies.org/different-ways-in-which-religion-and-populismintersect-within-worlds-great-faiths/, 9.06.2021.

Zander H. (2016), „Europäische” Religionsgeschichte: Religiöse Zugehörigkeit durch Entscheidung - Konsequenzen im interkulturellen Vergleich, De Gruyter, Berlin, Boston.

Zúquete J. P. (2017), Populism and Religion, w: The Oxford Handbook of Populism, red. C. Kaltwasser, P. Taggart, P. Espejo, P. Ostiguy, Oxford University Press, Oxford.

\section{"Unholy alliance"?: populism and the leading monotheistic religions}

\section{Summary}

Populism is one of the greatest challenges of today not only in terms of culture, society and politics, but also religion. Whether it is Judaism, Christianity or Islam, each of these religions, with their symbols, images, metaphors and parables, are exposed to an involuntary and "unholy alliance" with populism, which uses religion to achieve its own goals through political manipulation, the intensification of anti-immigrant attitudes, the devaluation of other social groups, as well as anti-establishment and anti-pluralism. The aim of this article is therefore to show the relationship that exists between the populist "thin-core ideology" and the main monotheistic religions within the ideological appropriation of religion by populists, which each time has the same "point of contact," i.e. the politicization of religion and the sacralization of politics.

Key words: populism, religion, Judaism, Christianity, Islam 
